Measuring the quality of politicians elected by gender quotas - are they any different?

Accepted for publication in Political Studies, June 2014

FINAL ACCEPTED VERSION

\author{
Peter Allen, University of Bath \\ David Cutts, University of Bath
}

Rosie Campbell, Birkbeck, University of London

Do gender quotas reduce the quality of politicians elected to a legislature? For the first time in the literature, we address this question by examining the quality of 'quota women' compared to their non-quota colleagues at three stages of their political career - their electoral performance, their qualifications for political office, and their post-election legislative career trajectories. Drawing on the unique case of Britain following the 1997 general election, we find no significant difference between the quality of 'quota women' and their non-quota colleagues. Voters do not punish 'quota women' at the ballot box; 'quota women' are as equally qualified for political office as their colleagues, and the gatekeepers of executive office do not discriminate against 'quota women' in frontbench promotions. Considering this, we conclude by asking whether the similarity of 'quota women' to their colleagues may actually impact their capacity to affect transformative substantive representation. 


\section{Measuring the quality of politicians elected by gender quotas - are they any different?}

In principle, people who have suffered discrimination shouldn't practise it. And in practise, women who've come through this route have skipped several steps so their skills may be deficient. Often they're women who've come through various women's organisations, and they're a bit....well, limp. It may explain why so few of Blair's Babes made any mark in the House of Commons.

(Edwina Currie, quoted by Ridge, 2013)

Even though gender quotas are increasingly used worldwide to speed up the process of getting more women into elected political office (Krook, 2010), they remain the subject of public debate and criticism. Opponents of gender quotas frequently cite the likely inferiority of 'quota women' compared to non-quota women and men (Bacchi, 2006; Franceschet and Piscopo, 2008; Murray 2010b).

But to what extent is this argument accurate? Is there any evidence that 'quota women' differ in their electoral performance, their qualifications for political office, and their descriptive representation at different levels of the legislative and executive hierarchy? While existing cross-national work has examined the impact of gender quotas (Franceschet and Piscopo, 2008; Murray, 2010; 2012; O'Brien, 2012; Sater, 2012), electoral behaviour (Cutts et al; 2008; Cutts and Widdop, 2012) and political career patterns (Franceschet and Piscopo, 2008; Murray, 2010a), this work has not considered the impact of sex and quotas over different stages of a political career. Here we seek to redress this imbalance in the literature by examining the impact of the all-women shortlist gender quota at the 1997 British general election on politicians' electoral performance in 1997, their qualifications for office, and finally their career trajectory once elected to the legislature in the period from 1997 to 2010. Our findings suggest that 'quota women' are not discriminated at the ballot box, are equally qualified, and are not perceived negatively by gatekeepers to the executive. These findings not only contribute to public debate and the expanding literature on equality guarantees and candidate quality, but also pose questions about whether such similarity restricts or enhances the potential for gender quotas to result in transformative substantive representation.

\section{Gender Quotas: Existing Evidence}

Numerous scholars have described how different countries, states, or regions adopt different types of gender quotas (Caul, 2001; Dahlerup and Friedenvall, 2010; Krook, 2010; 2013; O'Brien, 2012; Sater, 2012; Zetterberg, 2008). Quotas can be classified in four main ways : according to the source of their mandate (legal, constitutional, partisan); the strength of coercion behind their implementation; the stage at which they impact the electoral process, usually in terms of whether the focus is on inputs or outcomes (i.e. a quota focused on a minimum percentage of women across all electoral candidates or reserved seats within a legislature, respectively); and the ways in which they 'attempt to reform the dynamics of candidate selection' (Krook, 2013). Different types of quota disrupt the norms of existing 
political practice in varying ways and at different stages. Critics of gender quotas stress that these norms, embedded in the processes of candidate selection or electoral seat distribution, are meritocratic, and that gender quotas undermine this (Dahlerup, 2007; Dahlerup and Friedenvall, 2010; Murray, 2012). Rainbow Murray explains how this criticism assumes that 'by prioritizing traits such as sex over more objective measures of ability, gender quotas might jeopardize the quality of parliamentarians' (2012, p.27).

As such, scholars of gender quotas have generally utilised measures of candidate quality and success borne of comparing women elected to a legislature via a quota of some sort with those women and men who were not (Franceschet and Piscopo, 2012; Murray, 2010b, 2012; O'Brien, 2012). The dominant characteristics of men and women elected to a legislature prior to the implementation of a quota, including their political or occupational experience are seen as a de facto measure of quality. Following this logic, if women elected via a quota diverge from these patterns, they are deemed, to use the term of Murray, not 'up to the job' (2010b). It may be problematic to interpret any divergence in men and women's previous experience as an indicator of the inadequacy of women candidates; if women politicians' backgrounds map on to the structural inequalities generally faced by women in society then this constitutes at least part of the rationale for instituting a quota regime in the first place. Conceptions of merit may simply reflect dominant male attributes.

This article will adopt the position of much existing scholarship in this area, and assess the 'quality' of women elected to the House of Commons by 'All Women Shortlists' (AWS) in comparison to men and women elected through traditional means. Although there are clear normative questions raised by the assumptions underlying such an approach, we deem it still to be a useful method of assessing the impact of gender quotas in the British case and contextualising this in the existing literature. Despite their flaws, these measures are those most commonly used to assess the quality of politicians of both sexes, and as such, engaging with them not only locates our research within a broader body of comparative scholarship, but additionally speaks to non-academic writing on the topic of qualification for political office, highlighting its wider relevance (Oborne, 2007; Riddell, 1993).

\section{Measuring Candidate Quality: Existing Evidence}

Differences in the design of gender quotas, as well as case-specific institutional, cultural, and system-level differences mean that many existing findings are not directly generalizable to the British, or any other, case. The type of gender quota also affects the ease with which 'quota women' can be identified (Krook, 2009; 2013) For example, in the cases of both France and Argentina, the gender quota was a legislative quota, and as such, all women elected following its implementation could be dubbed 'quota women'. A contrasting case is that of Rwanda, which holds reserved seats for women in parliament whilst additionally electing women through traditional processes of selection also followed by men (Bauer, 2012; Bauer and Burnet, 2013; Devlin and Elgie, 2008). As such, 'quota women' are elected alongside other women who do not directly benefit from the use of a gender quota. Such a situation is similar to that in Britain, and this type of quota allows for the more effective 
untangling of the effect of gender quotas from broader sex effects (Dahlerup and Friedenvall, 2010).

\section{Electoral Performance}

In terms of electoral performance, a key question is whether or not voters punish 'quota women' candidates more than non-quota candidates from both sexes. Electoral performance can be interpreted as a measure of quality in the sense that if a party suffers from electoral decline following the implementation of a quota, this could reflect a perceived lack of quality on the part of the candidate by the voters. Cross national efforts to examine whether this is the case have been largely undermined by a lack of aggregate data, candidate information, the different types of electoral systems and the nature of the gender quota implemented. Moreover, any meaningful findings may also be subject to scepticism due to statistical issues such as selection bias because of the problem of unobserved heterogeneity and the possibility of endogeneity bias, both of which can lead to bias estimates if not corrected (Cutts and Widdop, 2012). Two notable exceptions stem from the British literature. In 2005, the British Labour party adopted 'all women shortlists' (AWS) in thirty constituencies and despite the election of 23 AWS candidates, the defeat of Maggie Jones in Blaenau Gwent (a traditional Labour heartland seat with a 19,000 majority) to ex-Labour Welsh AM Peter Law (who fought the election on an explicit anti-AWS ticket), brought the issue of gender quotas to the forefront of British politics. Even though some scholars, from descriptive evidence, claimed that AWS had a negative effect on Labour performance in 2005 (Curtice et al, 2005), another study questioned this perceived wisdom providing evidence that there was no significant antiAWS effect and that being a new candidate was far more important and one masked by AWS in 2005 (Cutts et al, 2008). A similar study of the 2010 election also found no evidence of anti-AWS effect, and this did not vary by incumbency status: any perceived AWS effect was not a sex effect but simply the result of being a new candidate (Cutts and Widdop, 2012).

\section{Qualifications for office}

Gender quotas themselves introduce a formal qualification for office, based on sex, that did not exist prior to their introduction. When scholars of quotas examine whether or not the women selected as a result of the quota are 'qualified', however, they focus their attention on the informal qualifications for office that did previously exist - primarily, age, education, occupational experience, and political experience (Franceschet and Piscopo, 2008; 2012; Murray, 2010b; 2012; O'Brien, 2012). Although these largely hold informal power (with the exception of legal restrictions on the minimum age of political candidates), the dominance of certain patterns renders them de facto qualifications.

It is common for national-level legislators to gain their first election to office in middle-age, with youth seen as an indicator of inexperience (Borchert and Zeiss, 2003). This is as true of women elected via a gender quota as any other politicians. In France and elsewhere, scholars have found no statistical differences between the ages of men, and quota and non-quota women in legislatures (Franceschet and Piscopo, 2012, Murray 2010b, 2012). The educational backgrounds of 'quota women' are also broadly similar to those of politicians 
elected through traditional means. While there is some evidence that women legislators in Argentina are significantly more likely to hold a degree than their male colleagues (Franceschet and Piscopo, 2012) other studies have found no statistically significant differences in the backgrounds of women holding reserved parliamentary seats and non-quota representatives of either sex (O'Brien, 2012).

Occupational and political experience is also considered to act as a de facto qualification for political office. Murray finds that the occupational and political backgrounds of women parliamentarians in France were slightly different from men; women were less often drawn from professional occupations, had less senior local political experience and had served fewer terms in local office; but crucially women elected in the parity period were more like male representatives than women elected before 2007 (Murray, 2010b; 2012). Such findings suggest that quotas help women overcome structural inequalities that limit their access to elected office (Murray, 2012). Evidence from Argentina suggests that women politicians are equally likely as men to have previously held legislative posts, although women do have less prior executive experience (Franceschet and Piscopo, 2012). In Uganda, reform of the quota regime, so that women are elected by the population rather than an elite electoral college, has led to the diversification of the backgrounds of 'quota women', who like their male colleagues remain members of the political elite but are no longer staunch party loyalists (O'Brien, 2012).

\section{Legislative careers and behaviour}

Within many political systems, true legislative and political power lies in executive positions. In order to reach these positions, legislators must convince gatekeepers of executive office that they are worthy of them. As such, being selected as suitable for executive office by its gatekeepers is an indication of perceived effectiveness or of political ability, both of which 'quota women' have been accused of not possessing. Is there evidence that, once elected, the legislative career and behaviours of 'quota women' differ from their non-quota colleagues, both male and female? Pär Zetterberg, in his study of Mexican 'quota women' in two state legislatures, finds 'that quota women are no more likely to suffer from tokenism, marginalisation or invisibilisation than other women legislators' (Zetterberg, 2008: p.455). Scholars of the Rwandan parliament also find 'no significant differences between the quota deputies and the directly elected deputies emerged' (Devlin and Elgie, 2008: p.245). In France, Murray finds no evidence that women elected after the introduction of parity legislation were less active in the legislature than men (Murray, 2010b).

\section{Britain: A case study approach}

Cross-national research on the impact of gender quotas remains limited reflecting the difficulties in generalising key findings across countries given the differences in both the nature of the quota as well as the institutional and cultural context of each individual case (Krook, 2013). For instance, criticisms of 'quota women' in a system implementing a legislative quota applicable to candidates from all political parties, elected using a system of proportional representation, will be different to a case where only some women within a 
single party are elected via a quota in a majoritarian electoral system. ${ }^{\mathrm{i}}$ And while some of the most informative scholarly work on quotas has been country specific case studies, no one has taken a holistic approach and examined sex and the impact of quotas - electoral performance, qualifications for office and legislative careers and behaviour - over time. Here we use Britain as a case study to do just that.

We use Britain for a number of reasons. Firstly, there is a recent history of quotas being used to select candidates for election to the Westminster parliament. In three of the last four general elections since 1992, the Labour party has used all women shortlists to select candidates in a specific number of constituencies. This provides us with the longevity to assess a subset of first time elected quota and non-quota candidates and examine any differences in terms of qualifications for office and subsequent legislative careers.

Secondly, Labour's commitment to equality guarantee has sparked political debate both within its own party and across the political spectrum and has led to much public furore since its introduction. The implementation of parliamentary sex quotas by the Labour party before the 1997 general election reflected both its commitment to parity of representation between women and men at Westminster and an electoral goal of reducing the Conservatives' historic advantage among women voters. In the 1997 general election, 38 AWS candidates were selected by their Labour constituency parties. Further legislation permitting the use of AWS was not enacted until after the 2001 general election, and following the decline in Labour women MPs from 101 to 95, it was reintroduced for the 2005 general election with 30 AWS candidates selected. The party encouraged the voluntary use of AWS where the sitting Labour MP was retiring, and threatened imposition if enough volunteer seats were not forthcoming (Cutts et al, 2008). Despite the loss of one its safest seats to an independent candidate standing on an anti-AWS ticket, Labour persevered with AWS in the 2010 general election, with 64 AWS candidates selected, 45 of who were in incumbent seats (Cutts and Widdop, 2012). Nonetheless, the quota issue continues to spark controversy in Britain and remains the subject of both public and political debate. As the former Liberal Democrat leader Paddy Ashdown recently commented, "I don't like women shortlists or shortlists for anybody. I find them illiberal and I find them demeaning to those who are put in that position, and I find them potentially insulting” (Ashdown quoted by Ridge, 2013).

Thirdly, due to cross-country variance in the type of quotas implemented, data suitability is often a key problem for scholars analysing their impact. It is even more of an issue if the aim is to examine differences in the quality of quota and non-quota candidates over time. To our knowledge, only in Britain are there existing datasets that can fulfil this task.

\section{Hypotheses}

Using Britain as a case study, we test the validity of claims that the quality of 'quota women', as candidates and elected politicians, differs from their non-quota colleagues at three stages of a political career. Differences in electoral performance allow us to assess whether voters distinguish between AWS candidates and candidates selected in a traditional way. Variations 
in the age, occupational and political experience, and education of representatives prior to election provide an assessment of the qualifications for office. Whilst variations in postelection political careers allow us to assess whether 'quota women' are perceived as less capable than their colleagues by the gatekeepers of executive office (in this case the Prime Minister), and combined with our findings on candidate quality, the veracity of this perception. As noted above, other country specific case studies have examined whether differences between quota and non-quota candidates exist. However, none of this scholarly work has examined a particular cohort through all three stages of a political career as we do here. Nonetheless, the existing literature does provide us with some expectations for our findings. As a consequence, from this literature, we test the following hypotheses:

H0(1): 'Quota women' do not differ from their non-quota colleagues in terms of their electoral performance in the 1997 general election.

HA(1) Being a 'Quota woman' had a negative effect on electoral performance relative to non-quota colleagues in the 1997 general election.

H0(2): 'Quota women' do not differ from their non-quota colleagues in terms of their age, occupational and political experience.

HA(2A, 2B) 'Quota women' differ from their non-quota colleagues in terms of their age and occupation (2A) and political experience (2B).

H0(3): 'Quota women' do not differ from their non-quota colleagues in terms of their legislative career path.

HA(3): 'Quota women' differ from their non-quota colleagues in terms of their legislative career path.

\section{The Data}

Our main source of data is the 1997 general election constituency data file. This aggregate level dataset is used to examine the three stages of a political career and contains electoral and political information for those candidates from the three main parties who stood for election in 1997. This aggregate file for all constituencies is used to determine whether the electoral performance of 'quota women' differed from non-quota candidates. However, to address the other two hypotheses relating to political experience and legislative career, we only use a subset of this file. This subset only contains those candidates, both quota and nonquota, elected for the first time in the 1997 general election.

For the first time, we examine whether selection as an AWS candidate in 1997 had a detrimental effect on their electoral performance. In total, there were 38 AWS candidates selected by constituency Labour parties to stand in the 1997 general election, seven of which were in Labour held seats (see Table 1). Of the 38 AWS candidates, three were unsuccessful: those standing in the Isle of Wight, Oxford West and Abingdon and Woodspring. Our 
constituency level dataset contains variables that differentiate candidate status by sex, quota, and incumbency. In order to test possible relationships between 'quota women' and Labour party performance it was necessary to construct additional variables. Ten socio-economic variables were obtained from the 1991 census to reflect established social cleavages (Cutts, 2006), and a principal components analysis was run to remove any potential collinearity from the variables (see Appendix A1 for full details). Three factors were extracted and saved in the dataset that clearly reflected the characteristics of the parliamentary constituencies. Factor 1 captures the class structure; Factor 2 describes the affluent suburban constituencies, while Factor 3 reflects the more rural constituencies with an ageing population. We also include the sex of candidate variable for both opposition parties (Cutts and Widdop, 2012). Historically, sex discrimination has existed in all of the main parties' selection procedures despite no evidence of an electoral penalty for women candidates in British elections (Cutts et al, 2008; Lovenduski, 2001). We also derive party spending variables as measures of local campaigning given the established impact of party activism on electoral outcomes (Cutts, 2006; Fieldhouse and Cutts; 2009). While the inclusion of demographic and other controls allows us to gauge the underlying pattern of support for Labour, in order to provide a rigorous test of whether there was an AWS effect in 1997, we also derive a prior vote share variable to take account of other factors not accounted for in the previous analyses.

Table 1: All Women Shortlist Candidates in the 1997 General Election

\begin{tabular}{|l|l|l|l|c|}
\hline AWS 1997 Non-Incumbent Seat & Candidate & Region & Winning Party 92 & Lab Behind 92 \\
\hline 1. Aberdeen South & Anne Begg & Scotland & Conservatives & $13.46 \%$ \\
\hline 2. Amber Valley & Judy Mallaber & EM & Conservatives & $2.10 \%$ \\
\hline 3. Basildon & Angela E Smith & E.Anglia & Conservatives & $4.37 \%$ \\
\hline 4. Birmingham Edgbaston & Gisela Stuart & WM & Conservatives & $9.94 \%$ \\
\hline 5. Brentford and Isleworth & Ann Keen & London & Conservatives & $2.83 \%$ \\
\hline 6. Burton & Janet Dean & WM & Conservatives & $6.99 \%$ \\
\hline 7. Calder Valley & Chris McCafferty & Y\&H & Conservatives & $7.98 \%$ \\
\hline 8. Cardiff North & Julie Morgan & Wales & Conservatives & $6.22 \%$ \\
\hline 9. Cleethorpes & Shona McIsaac & Y\&H & Conservatives & $12.02 \%$ \\
\hline 10. Colne Valley & Kali Mountford & Y\&H & Conservatives & $12.23 \%$ \\
\hline 11. Conwy & Betty Williams & Wales & Conservatives & $7.97 \%$ \\
\hline 12. Crawley & Laura Moffat & SE & Conservatives & $3.65 \%$ \\
\hline 13. Erewash & Liz Blackman & EM & Conservatives & $9.01 \%$ \\
\hline 14. Falmouth \& Camborne & Candy Atherton & SW & Conservatives & $7.70 \%$ \\
\hline 15. Isle of Wight & Deborah Gardiner & SE & Conservatives & $41.92 \%$ \\
\hline 16. Keighley & Ann Cryer & Y\&H & Conservatives & $6.56 \%$ \\
\hline 17. Luton South & Margaret Moran & SE & Conservatives & $1.03 \%$ \\
\hline 18. Mitcham \& Morden & Siobhan McDonagh & London & Conservatives & $3.39 \%$ \\
\hline 19. Milton Keynes SW & Phyllis Starkey & SE & Conservatives & $9.16 \%$ \\
\hline 20. Northampton North & Sally Keeble & EM & Conservatives & $7.17 \%$ \\
\hline 21. Oxford West \& Abingdon & Susan Brown & SE & Conservatives & $30.11 \%$ \\
\hline 22. Peterborough* & Helen Clark & E.Anglia & Conservatives & $11.70 \%$ \\
\hline 23. Plymouth Sutton & Linda Gilroy & SW & Conservatives & $2.01 \%$ \\
\hline
\end{tabular}




\begin{tabular}{|l|l|l|l|c|}
\hline 24. Preseli Pembrokeshire & Jackie Lawrence & Wales & Conservatives & $1.38 \%$ \\
\hline 25. Redditch & Jacqui Smith & WM & Conservatives & $6.75 \%$ \\
\hline 26. Stirling & Anne McGuire & Scotland & Conservatives & $0.56 \%$ \\
\hline 27. Stockton South & Dari Taylor & North & Conservatives & $9.44 \%$ \\
\hline 28. Stourbridge & Debra Shipley & WM & Conservatives & $10.56 \%$ \\
\hline 29. Welwyn Hatfield & Melanie Johnson & SE & Conservatives & $11.53 \%$ \\
\hline 30. Wolverhampton SW & Jenny Jones & WM & Conservatives & $9.43 \%$ \\
\hline 31. Woodspring & Debbie Sander & SW & Conservatives & $40.94 \%$ \\
\hline AWS 1997 Incumbent Seat & Candidate & Region & Second Party 92 & Lab Maj $\mathbf{9 2}$ \\
\hline 1. Ayr, Carrick and Cumnock & Sandra Osborne & Scotland & Conservatives & $4.18 \%$ \\
\hline 2. Forest of Dean & Diana Organ & SW & Conservatives & $1.40 \%$ \\
\hline 3. Lincoln & Gillian Merron & EM & Conservatives & $1.86 \%$ \\
\hline 4. Liverpool, Garston & Maria Eagle & NW & Conservatives & $26.09 \%$ \\
\hline 5. Liverpool, Riverside & Louise Ellman & NW & Lib Dems & $57.56 \%$ \\
\hline 6. Regents Park \& Kensington N & Karen Buck & London & Conservatives & $7.28 \%$ \\
\hline 7. Slough & Fiona Mactaggart & SE & Conservatives & $0.07 \%$ \\
\hline
\end{tabular}

*Helen Brinton (later Clark)

To examine political experience, we took a subset of this aggregate level dataset and added details of the demographic, personal, occupational and political characteristics of those 178 Labour MPs elected to the House of Commons for the first time in 1997. Of these 178 elected MPs, 64 were women, with 35 of those women elected through all-women-short-lists. This newly elected cohort also included those 40 Labour MPs elected for the first time at the 2005 general election, 26 of whom were women and 14 men. ${ }^{\text {ii }}$ Put simply, this data allows us to compare the age, previous occupation, educational attainment and previous political experience of 1997 Labour entrants; all of which have been used as measures of 'quality' in other studies (Franceschet and Piscopo, 2012; Murray, 2010b; O’Brien, 2012).

Finally, using the same newly elected 1997 cohort, we compare the post-election career trajectories of Labour parliamentarians first elected in 1997, asking whether these trajectories differ for those women selected from an AWS compared to their colleagues selected through traditional methods. This cohort provides us with an unprecedented opportunity to look at the career paths of quota and non-quota legislators developing alongside one another across a thirteen-year period in an identical context compared to existing studies of Western democracies which have been able to compare only women who were elected before and after the introduction of a quota (Murray, 2010a,b). ${ }^{\text {iii }}$ Here we collate post-election career trajectory data for the 1997 newly elected cohort and add them to the existing aggregate dataset. Our analysis also takes account of candidate quality measures outlined above along with additional covariates such as MP tenure (whether the MP served the full thirteen years or not) and electoral majority obtained by the newly elected MP in the 1997 general election.

\section{Electoral performance: Do 'quota women' fare worse than non-quota candidates?}

The 1997 general election proved fruitful for AWS candidates with 35 of the 38 being elected. Table 2 details how AWS candidates fared in comparison to Labour incumbents and new candidates. As a whole, AWS candidates fared much better than new non-quota women candidates, the vast majority of whom were selected in non-winnable seats, but there was 
little difference between them and new candidates as whole or by sex. Those AWS candidates in non-incumbent seats recorded the best performance. There is also little difference in the performance between AWS candidates standing in incumbent seats and nonquota incumbent performance irrespective of sex. The descriptive evidence also suggests that the performance of AWS candidates did not significantly differ from non-quota candidates, other than new non-quota women candidates, the majority of which stood in opposition strongholds. However, to test whether there was any difference in any electoral performances between quota and non-quota candidates, it is necessary to take account of intervening variables - social cleavages and other electoral influences on Labour support - using a series of multivariate analyses.

Table 2: Labour Performance in the 1997 General Election: Candidate Sex, Incumbent Candidate Sex, New Candidates and Sex, and All Women Shortlists

\begin{tabular}{|c|c|c|}
\hline Candidates & $\begin{array}{c}\text { Mean \% } \\
\text { LABVS } 1997\end{array}$ & $\begin{array}{c}\text { Mean \% LABVS } \\
+/-92-97\end{array}$ \\
\hline \multicolumn{3}{|l|}{ Labour Candidate Sex } \\
\hline All Labour Woman Candidates (159) & $43.10 \%$ & $+9.24 \%$ \\
\hline All Labour Male Candidates (481) & $46.61 \%$ & $+9.61 \%$ \\
\hline \multicolumn{3}{|l|}{ Labour Incumbent Candidates } \\
\hline Labour Incumbent Candidates (238) & $60.95 \%$ & $+8.73 \%$ \\
\hline \multicolumn{3}{|l|}{ Labour Incumbent Seats \& Candidate Sex } \\
\hline Women Incumbent Candidates ${ }^{1}(39)$ & $57.50 \%$ & $+8.46 \%$ \\
\hline Male Incumbent Candidates (199) & $61.62 \%$ & $+8.79 \%$ \\
\hline \multicolumn{3}{|l|}{ New Candidates \& Sex } \\
\hline All New Candidates (403) & $36.78 \%$ & $+9.99 \%$ \\
\hline All New Women Candidates ${ }^{2}(120)$ & $38.41 \%$ & $+9.49 \%$ \\
\hline All New Male Candidates (283) & $36.09 \%$ & $+10.21 \%$ \\
\hline All New Women Non AWS candidates (82) & $33.80 \%$ & $+8.95 \%$ \\
\hline \multicolumn{3}{|l|}{ New Candidates: All Women Shortlists } \\
\hline All Women Shortlist Candidates (38) & $48.37 \%$ & $+10.66 \%$ \\
\hline All Women Shortlist Candidates (Incumbent) (7) & $57.13 \%$ & $+8.11 \%$ \\
\hline All Women Shortlist Candidates (Non-Incumbent) (31) & $46.39 \%$ & $+11.23 \%$ \\
\hline
\end{tabular}

${ }^{1}$ Includes AWS incumbent candidates (7). ${ }^{2}$ Includes all AWS candidates (38). Note that all 1992 seat type and vote is based on 1992 notional vote shares due to extensive redistricting in 1997.

To test these relationships we use standard OLS regression models. Previous evidence from the 2010 and 2005 general election suggests that AWS seats are selected according to number of criteria including the proximity to other women, seats where the retired incumbent was a woman, region, early selection in the electoral cycle and, in some cases, the marginality 
(Cutts et al, 2008). As a consequence, there is a possibility of selection bias, unobserved heterogeneity and endogeneity bias which may cause inconsistent estimates if they are not deal with appropriately (Cutts and Widdop, 2012). Here we attempted to use an instrumental variable (IV) approach (Angrist et al, 1996) and propensity score matching (Rosenbaum and Rubin, 1985) with limited success. For instance, the instruments used lacked explanatory power in the first stage of the model, and their continued use in the modelling process could themselves lead to biased estimates. ${ }^{\text {iv }}$ After calculating propensity scores, we found little difference between AWS and non-AWS seats, although this finding must be treated with caution given that the method is dependent on re-estimating the propensity score until the distribution is fairly similar between control and treatment groups, and our sample of the treatment group (in this case AWS seats) is relatively small. ${ }^{v}$ Given the unreliability of these estimates, it was decided to use conventional OLS regression models.

Previous evidence suggests that if AWS candidates suffer an electoral penalty then it is because of being new candidates rather than being women or being selected by a quota (Cutts et al, 2008; Cutts and Widdop, 2012). Here we split our quota variable by incumbency to reflect that AWS candidates were selected to stand both in incumbent and non-incumbent seats. We also include two separate new candidate variables - for women and men standing in non-incumbent seats - who weren't selected by a quota. These are compared against incumbent candidates, both men and women. The linear models are built incrementally over three stages to examine how these quota and non-quota variables are affected when other covariates are added. The first stage is the null model and includes the main variables of interest without any additional covariates. The second stage includes three socio-economic factors that capture the social cleavages in voting patterns, control variables to measure the sex of Conservative and Liberal Democrat candidates as well these parties' campaign spending, which act as a proxy for local campaigning. The final stage takes account of previous Labour vote share in 1992. This alters the interpretation of the model by determining the influence of these variables on Labour vote change where continuity of support is held constant (Cutts and Widdop, 2012). 
Table 3: OLS Regressions: Impact of Quota and Non-Quota Candidates on Labour Support in the 1997 General Election

\begin{tabular}{|c|c|c|c|}
\hline \multirow[t]{2}{*}{ Variables } & Model 1 & Model 2 & Model 3 \\
\hline & SE & SE & SE \\
\hline Constant & $59.18 *(1.44)$ & $53.39 *(3.92)$ & $12.25 *(2.80)$ \\
\hline \multicolumn{4}{|l|}{$\begin{array}{l}\text { Base: All Labour Incumbent } \\
\text { Candidates }\end{array}$} \\
\hline AWS (Quota) Incumbent & $-10.75(11.80)$ & $(7.85)$ & $-2.28 \quad(3.59)$ \\
\hline AWS (Quota) Non-Incumbent & $-15.89 *(5.43)$ & $(3.98)$ & $2.47 \quad(1.83)$ \\
\hline $\begin{array}{l}\text { Labour New Non-Quota Woman } \\
\text { Candidates (non-incumbent) }\end{array}$ & $-33.99 *(3.81)$ & $-15.53 *(3.07)$ & $-3.48 *(1.54)$ \\
\hline $\begin{array}{l}\text { Labour New Non-Quota Male } \\
\text { Candidates (non-incumbent) }\end{array}$ & $-24.40 *(2.68)$ & $-9.13 *(2.21)$ & $-0.43 \quad(1.11)$ \\
\hline \multicolumn{4}{|l|}{ Opposition Candidates } \\
\hline Gender Conservative Candidate & - & $1.27 \quad(2.26)$ & $0.39 \quad(1.03)$ \\
\hline Gender Lib Dem Candidate & - & $-0.43 \quad(1.80)$ & -0.40 \\
\hline \multicolumn{4}{|l|}{ Social Cleavages } \\
\hline Factor 1: 'Working class' & - & $3.68 * \quad(1.19)$ & $0.04 \quad(0.58)$ \\
\hline Factor 2: 'Affluent suburbs' & - & $-3.76^{*}(0.94)$ & $-0.43 \quad(0.45)$ \\
\hline Factor 3: 'Retirement and Rural' & - & $-0.89 \quad(1.05)$ & $-0.95 *(0.47)$ \\
\hline \multicolumn{4}{|l|}{ Party Campaigning } \\
\hline Labour 1997 Spending & - & $0.16^{*} \quad(0.04)$ & $0.05 *(0.02)$ \\
\hline Conservative 1997 Spending & - & $-0.07 \quad(0.04)$ & $0.01 \quad(0.02)$ \\
\hline Lib Dem 1997 Spending & - & $-0.14 *(0.03)$ & $-0.04 * \quad(0.02)$ \\
\hline Nationalist 1997 Spending & - & $-0.13 *(0.03)$ & $\begin{array}{ll}-0.02 \quad(0.02) \\
\end{array}$ \\
\hline \multicolumn{4}{|l|}{ Previous Vote Share } \\
\hline \% 1992 Labour vote share & - & - & $0.83 *(0.04)$ \\
\hline \multicolumn{4}{|l|}{ Model Fit } \\
\hline $\mathrm{R}^{2}$ & 0.57 & 0.84 & 0.97 \\
\hline
\end{tabular}

$*<0.05=$ significant

Table 3 contains the results of the regression analyses. Following the inclusion explanatory variables, the $\mathrm{R}^{2}$ values show that these explain 84 per cent of the variation in 1997 Labour vote share. This increases to 97 per cent when previous Labour vote share is added. In model one, both quota and non-quota new candidates standing in non-incumbent seats have a significant negative effect on 1997 Labour vote share when compared against incumbent candidates. The coefficients are much larger for new non-quota candidates than AWS candidates suggesting that the latter performed relatively well compared to this group. Interestingly, there was no significant difference between AWS candidates standing in incumbent seats and non-quota incumbent candidates. Put simply, being selected by quota in an incumbent seat made little difference to Labour's electoral performance in 1997. Closer inspection of the model with socio-economic cleavages and campaign influences on Labour support reveals that this finding holds with no additional penalty for AWS candidates in incumbent seats. The inclusion of covariates in model two, however, does reveal that AWS 
candidates standing in non-incumbent seats fared much better than new non-quota candidates, with the latter for both men and women remaining negatively significant at the 95 per cent level, while the former was insignificant.

This model seems robust with the explanatory variables influencing 1997 Labour vote share in ways that one would expect: for instance, the more Labour campaigned, the higher their vote share; Labour did better in working class areas and their vote was lower in affluent suburban constituencies. After controlling for social cleavages and other factors, it seems that AWS candidates in non-incumbent seats actually performed better than other new candidates and didn't perform significantly better or worse than those incumbent candidates standing in Labour held seats. Even when prior vote is controlled for, this finding holds, with new nonquota women standing in non-incumbent seats performing significantly worse than men nonquota and quota women candidates, when compared against Labour incumbent candidates. In a similar manner, there is no significant difference, when previous vote shared is added, between non-quota and AWS incumbent candidates. Our findings suggest that there is clearly no evidence of an AWS effect. Labour did not suffer an electoral penalty in 1997 where they selected AWS candidates whether it was in seats they previously held or where they were challenging, and thus we can reject $\mathrm{HA}(1)$.

\section{Candidate quality: Are elected 'quota women' less qualified than newly elected non- quota candidates?}

A number of candidate characteristics and measures of political experience have been generally accepted as proxies for 'qualifications' for office to highlight differences and similarities between 'quota women' and other parliamentarians of both sexes (Franceschet and Piscopo, 2012; 2008; Murray, 2010b; 2012). Differences might suggest a disparity of notional preparedness for office in some direction between the two groups, whereas similarity would suggest otherwise. To test these differences, we examine a subset of 178 newly elected candidates - both quota and non-quota - at the 1997 general election. We employ a series of bivariate regression analyses to examine the relationship between the process of selection (by quota or not), their demographic characteristics and their political quality. As noted above, the inconsistent implementation of the AWS policy allows us to distinguish between sex and quota effects.

Our first set of analyses examines the relationship between the process of selection, age and education. Eleven of the twenty nine newly elected non-quota women were under the age of 40 with three elected MPs under the age of 30. Only three of the 114 new elected non-quota male candidates were under 30. There were no 'quota women' aged less than 30 and only five of the 35 elected under the age of 40. Closer inspection of the data suggests that there is actually little difference in the average age of quota and non-quota newly elected MPs: on average, newly elected non-quota men were aged 44; non quota women were 42 and quota women were 45 . This is borne out in the bivariate OLS regressions. There is no statistically significant difference between AWS women and those elected from seats which held open 
selection contests. This finding holds when both AWS women and non-quota women are compared against newly elected non-quota men. ${ }^{\text {vi }}$ A similar story is evident when we examine education. More than $75 \%$ of those newly elected MPs - both quota and non-quota and irrespective of sex - either had an undergraduate degree or better. As a consequence, there was no significant difference in education between 'quota women' and non-quota elected MPs or where non-quota MPs was differentiated by sex, and we can reject HA(2A). ${ }^{\text {vii }}$

Alongside age and education there are three other measures of 'political quality' used in the existing literature: having previously contested a parliamentary election, experience of serving on a local legislature, and occupational experience in national politics. The 'blooding' of candidates is a common form of political experience in Britain, whereby candidates run for election in parliamentary seats considered unwinnable for their party as a rite of passage (Norris and Lovenduski, 1995). This is arguably a useful measure of 'quality' in the British case, acting as a direct measure of political experience as well as a proxy measure of party loyalty. It is also common in Britain for legislators at the national level to have had previous experience of politics at a local level, most notably through elected service on local councils. In terms of candidate selection process, local experience is widely considered to be a positive attribute as it provides candidates with local contacts, practical experience, and public exposure (Norris and Lovenduski, 1995). In recent decades, British MPs have increasingly entered the House of Commons following prior employment in national politics, such as being a staffer for a political party or holding a position in the press which involves contact with the political world (Allen, 2013). Having professional occupational experience in politics provides an opportunity for an individual to spend time at Westminster, often in close proximity to sitting politicians, and to make contacts which may prove useful when either seeking selection for a parliamentary seat, or indeed when seeking ministerial promotion if elected. On the other hand, having such experience may leave 'quota women' open to charges of leadership nepotism, as seen in other countries using gender quotas (Sater, 2012).

But are newly elected quota women less qualified than their non-quota colleagues? Here we test for any relationship between newly elected quota women and non-quota MPs and these measures of 'political quality' separately using a series of bivariate binary logistic regressions. The results are shown in Table 4. Our findings suggest that 'quota' women are no more likely to have contested a parliamentary seat or have experience of being a local councillor than non-quota newly elected MPs (see Model 1a and 2a). Even when we differentiate non-quota elected MPs by sex (Models $1 b$ and 2b), quota and non-quota women are less likely than men to hold electoral experience at the national or local level, but neither are significant at the $95 \%$ level, although the former is at the $90 \%$ level. Model $3 \mathrm{a}$ and $3 \mathrm{~b}$ test for any differences in occupational experience between newly elected quota and non-quota MPs. Although 'quota women' are more likely to have more occupational political experience than non-quota MPs, this isn't significant at the 95\% level. When we differentiate non-quota MPs by sex (see Model 3b), we find evidence of a sex effect with non-quota women significantly more likely to have occupational experience in politics than non-quota men. The coefficient for 'quota woman' remains positive and insignificant. In sum, we can reject $\mathrm{HA}(2 \mathrm{~B})$. 
Table 4: Logistic Regressions: Impact of Quota and Non Quota MPs on Measures of 'Candidate Quality'

\begin{tabular}{|c|c|c|c|}
\hline Variables & $\begin{array}{c}\text { Model 1a } \\
\text { Contested } \\
\text { Parlt Election }\end{array}$ & $\begin{array}{c}\text { Model 2a } \\
\text { Been a Local } \\
\text { Councillor }\end{array}$ & $\begin{array}{c}\text { Model 3a } \\
\text { Worked in } \\
\text { Politics }\end{array}$ \\
\hline & & & SE \\
\hline Constant & $0.32 \quad(0.17)$ & $0.95 *(0.19)$ & $0.59 *(0.18)$ \\
\hline \multicolumn{4}{|c|}{$\begin{array}{l}\text { Base: Non-Quota( Open List) } \\
\text { MPs }\end{array}$} \\
\hline AWS (Quota) MPs & $-0.20 \quad(0.39)$ & $-0.03 \quad(0.42)$ & $0.53 \quad(0.38)$ \\
\hline \multicolumn{4}{|l|}{ Model Fit } \\
\hline -2 Log Likelihood & 240.70 & 211.39 & 234.81 \\
\hline \multirow[t]{3}{*}{ Nagelkerke $\mathrm{R}^{2}$} & 0.02 & 0.00 & 0.02 \\
\hline & $\begin{array}{c}\text { Model 1b } \\
\text { Contested } \\
\text { Parlt Election }\end{array}$ & $\begin{array}{c}\text { Model 2b } \\
\text { Been a Local } \\
\text { Councillor }\end{array}$ & $\begin{array}{c}\text { Model 3b } \\
\text { Worked in } \\
\text { Politics }\end{array}$ \\
\hline & SE & SE & SE \\
\hline Constant & $0.18 \quad(0.19)$ & $1.22 *(0.22)$ & $-0.77 *(0.20)$ \\
\hline \multicolumn{4}{|c|}{$\begin{array}{l}\text { Base: Male Non-Quota( Open } \\
\text { List) MPs }\end{array}$} \\
\hline AWS (Quota) MPs & $-0.35 \quad(0.40)$ & $-0.21 \quad(0.43)$ & $\begin{array}{ll}0.72 \quad(0.39) \\
\end{array}$ \\
\hline $\begin{array}{l}\text { Non-Quota( Open List) } \\
\text { Women MPs }\end{array}$ & $\begin{array}{ll}-0.79 & (0.46)\end{array}$ & $\begin{array}{ll}-0.77 \quad(0.44) \\
\end{array}$ & $0.84 *(0.42)$ \\
\hline \multicolumn{4}{|l|}{ Model Fit } \\
\hline -2 Log Likelihood & 237.50 & 208.32 & 230.85 \\
\hline Nagelkerke $\mathrm{R}^{2}$ & 0.03 & 0.03 & 0.04 \\
\hline
\end{tabular}

$*<0.05=$ significant

The measures of 'political quality' assessed in Table 4 suggest that the political backgrounds of 'quota women' are a little closer to those of men, particularly in terms of contesting parliamentary elections and being a local councillor, than that of women elected from open lists. Are such findings counter-intuitive? To some extent, they run contrary to criticisms of gender quotas which focus on candidate quality as they suggest that, in fact, by accepted metrics, 'quota women' are actually better qualified than non-quota women (Dahlerup and Friedenvall, 2010). One possible explanation lies in the fact that all AWS selections for the 1997 general election had to occur relatively early in the electoral cycle, at least 16 months prior to the general election itself. Those candidates who had previously sought seats unsuccessfully may have put themselves forward for selection earlier in the cycle, whilst first-time candidates may have taken longer to make the decision to run. By the common metrics used to measure 'quality', these candidates with greater previous political involvement are more qualified. Similarly, the AWS policy was largely focused on those seats which Labour had either previously held or was likely to be highly competitive in the general election. Given the targeting strategy of the party in 1997, it is possible that these seats were home to extremely active local constituency organisations which counted numerous 'qualified' women in their ranks. It could be the case that the party targeted seats 
where a likely woman candidate was already in place, so as to avoid unnecessary rancour between centre and periphery (Childs and Cowley, 2011).

Additionally, this can be linked to debates within the literature on gender quotas, as well as women in politics more broadly, which question the 'double bind' that many women politicians face (Franceschet, Krook and Piscopo, 2012; Murray, 2010b). Women politicians, including those elected through the use of a gender quota are generally expected to replicate existing norms of pre-legislative political experience There is often pressure on women in politics to be transformative in some way and to disrupt male norms of political behaviour (Cowley and Childs, 2003; Lovenduski, 2005). A clear tension exists here, and as a consequence, it is perhaps not that surprising that quota women were not that different from their male non-quota colleagues, as such similarity is an informal prerequisite for successfully becoming a national-level politician.

\section{Political Careers: Are elected 'quota women' less likely to achieve high office than newly elected non-quota candidates?}

Much of the scholarly work which addresses the impact of gender quotas focuses on either the descriptive representation of women in political legislatures and executives or the ways in which this 'presence' affects substantive representation (Childs and Krook, 2009; Murray, 2012). Here we focus on the descriptive representation of women in 1997 across different levels of the parliamentary and executive hierarchy. ${ }^{\text {viii }}$ There is a hierarchy of offices within British government. Beginning at the top, Cabinet positions rank highest, followed by Ministers of State, then Under-secretaries of state, and finally parliamentary private secretaries (PPS). Many MPs do not achieve any of these offices and remain on the backbenches for the duration of their time in the Commons. ${ }^{\text {ix }}$ Owing to sample size considerations, we combine cabinet and minister of state positions, which gives us a scale of four different levels of office. For the purpose of our analysis, this is used as our dependent variable to measure career success in the years up until the 2010 election and the removal of the Labour government, or when an MP left parliament through retirement or electoral loss, whichever comes first.

Because the dependent variable has ordered categories, we employ an ordered logistic model to test for whether there are any significant differences in the post-election legislative career of quota and non-quota MPs. ${ }^{x}$ We also include the measures of 'political quality' used earlier to examine, for example, whether those MPs with previous political experience are significantly more likely to progress up the legislative career ladder. Two additional covariates are also added: tenure of the MP and a MPs electoral majority in 1997. The former is a binary variable which takes account of whether those elected in 1997 remained an MP until 2010. Of the 178 new Labour cohort in 1997, 15 retired, one died and 34 were defeated at the ballot box before the 2010 general election. Put simply, incumbency over the thirteen years was not wholly dependent on the marginality of the seat. We also take account of a MPs electoral majority in 1997. Those quota and non-quota MPs elected in safe seats are more likely to have greater longevity, notwithstanding death or retirement. However, it is also possible that parties may be more likely to select a talented, potential 'high flyer' in a safe 
seat to ensure that such experience, expertise and ability can be utilised in executive positions for a considerable length of time. As such, this variable also acts as a proxy for potential talent and ability.

The main findings and the model fit statistics from the ordered logistic model are shown in Table 5. When compared against men non-quota MPs, we find that being a newly elected AWS quota MP or a non-quota women MP did not have any significant influence on a MPs post-election legislative career. This finding is hardly surprising. Only five women in the newly elected 1997 cohort made it to Cabinet level: Yvette Cooper was Secretary of State for Work and Pensions, Hazel Blears for Communities and Local Government, Patricia Hewitt for Health (and Trade and Industry), Ruth Kelly for Transport (and Education and Communities and Local Government), and Jacqui Smith was Home Secretary. Of this group, Jacqui Smith is the only one to be selected from an AWS, but in terms of office achievement, she arguably held the most prestigious of all those listed here, with Home Secretary being one of the four 'Great Offices of State' (Berlinski, et al, 2007). As a consequence, any argument which claims that 'quota women' were discriminated against by the gatekeepers of executive office is difficult to substantiate and we can reject $\mathrm{HA}(3)$. The models in Table 5 suggest that overall they were not, but given that more women were elected through AWS than women from an open list, their general lack of presence in the executive is a little surprising.

Table 5: Ordered Logistic Regression: Impact of Quota and Non Quota MPs on PostElection Legislative Career

\begin{tabular}{|c|c|c|c|}
\hline Variables & SE & bStdXY & SDofX \\
\hline \multicolumn{4}{|l|}{ Base: Male Non-Quota( Open List) MPs } \\
\hline AWS (Quota) MPs & $-0.03 \quad(0.36)$ & -0.01 & 0.40 \\
\hline Non-Quota( Open List) Women MPs & $0.04 \quad(0.39)$ & 0.01 & 0.37 \\
\hline \multicolumn{4}{|l|}{ Candidate Quality } \\
\hline Age & $-0.12 *(0.02)$ & -0.40 & 7.38 \\
\hline Degree level Education & $0.93 *(0.38)$ & 0.17 & 0.41 \\
\hline Occupational Political Experience & $0.06 \quad(0.32)$ & 0.01 & 0.49 \\
\hline Previously Contested Parliamentary Seat & $-0.17 \quad(0.32)$ & -0.04 & 0.49 \\
\hline Local Councillor & $0.04 \quad(0.44)$ & 0.01 & 0.45 \\
\hline \multicolumn{4}{|l|}{ Additional Covariates } \\
\hline Tenure of MP & $1.25 *(0.44)$ & 0.26 & 0.46 \\
\hline Electoral Majority in 1997 & $0.04 *(0.02)$ & 0.22 & 13.63 \\
\hline \multicolumn{4}{|l|}{ Model Fit } \\
\hline Pseudo Log Likelihood & \multicolumn{3}{|c|}{-194.02} \\
\hline Wald Chi-Square & \multicolumn{3}{|c|}{$56.81 *$} \\
\hline Nagelkerke $\mathrm{R}^{2}$ & \multicolumn{3}{|c|}{0.14} \\
\hline
\end{tabular}

$$
*<0.05=\text { significant }
$$


A number of the candidate quality measures - previously contested a parliamentary election, experience as a local councillor, occupational political experience - also had no effect. But age and education did matter: the younger the MP in 1997 the more likely they were to achieve the higher executive positions; those MPs with degrees were significantly more likely to be employed in the executive.$^{\mathrm{x}}$ To gauge the effects of these variables, we can interpret the $\mathrm{Y}$-standardized and fully standardized coefficients as the change (measured in standard deviations) in latent $\mathrm{Y}$ variable per unit of $\mathrm{X}$ or per standard deviation of $\mathrm{X}$. In this case, a one standard deviation increase in age (which is 7.4 years) decreases an MP achieving an executive position during their legislative career by .40 standard deviations. As regards education, one standard deviation increase in having a degree increases whether a MP reaches top office by .17 standard deviations. Those MPs who remained in Westminster for the duration of the Labour government from 1997 to 2010 were significantly more likely to gain executive office. This was also the case for those newly elected MPs who had the largest electoral majorities in 1997. A one standard deviation increase in electoral majority (which is 13.63 per cent) increases whether a MP served in the executive during Labour's thirteen year period in power by 0.22 standard deviations.

\section{Conclusion}

In this article, we have measured the quality of women elected via a gender quota at three stages of their political careers - their electoral performance in 1997, their pre-legislative qualifications for office, and their post-election legislative careers. Overall, we find very few statistically significant differences between the performance on these metrics of 'quota women' compared to their male and female colleagues elected without the use of a gender quota.

We found no evidence of an AWS effect in 1997 and were able to reject HA(1). Labour did not suffer any electoral penalty in 1997 where they selected quota or AWS candidates whether it was in challenging or incumbent seats. Interestingly there was some evidence that new non-quota women standing in non-incumbent seats performed significantly worse than men non-quota and quota women candidates. However, this may have reflected the late selection of these seats given the relatively early selection of AWS candidates, and possibly the disproportionate selection of non-quota women in unwinnable seats, with the remaining priority seats more likely to be taken by men (Childs, 2000). In terms, of their levels of education, age at time of election, and other multiple measures of political 'quality, we found no evidence of any significant differences between quota and non-quota MPs and can reject HA (2A, 2B). If anything, particularly in the case of standing previously for Westminster and being a local councillor, newly elected AWS MPs were a little closer to men than women elected through open lists. Finally, we found no significant difference in the post-election career trajectories of AWS women and their colleagues within the House of Commons and can reject $\mathrm{HA}(3)$. Crucially, we find no significant relationship between being elected through a gender quota and the attainment of higher executive office, a finding that resembles those of existing research (Bauer and Burnet, 2013; Murray, 2010b). 
Put simply, we contend that the evidence presented here demonstrates that 'quota women' are not discriminated against by voters, are equally qualified for office as their colleagues and are not perceived negatively by the gatekeepers to executive office. Although limited to Britain in terms of generalizability by virtue of the data, these findings contribute to an expanding literature that considers the interaction of equality guarantees and candidate quality. Our findings additionally hold relevance for the wider gender and politics literature, raising questions of how the descriptive representation of 'quota women' in executive roles affects the substantive representation of women. They also raise questions about the aims of gender quotas, specifically the relationship between the descriptive numeric representation of women and their substantive representation. To what extent is it normatively desirable for women elected via a gender quota to hold social, educational, and political backgrounds which are broadly similar to the men who have previously dominated political legislatures? (Childs and Krook, 2012; Franceschet, Krook and Piscopo, 2012) As interest in the ideas of a political class and the professionalization of politics grow (Borchert and Zeiss, 2003; Oborne, 2007), this article provides an insight into how gender quotas fit into this debate, highlighting the overall similarity of British 'quota women' to their colleagues, both male and female, selected through traditional procedures. Whether or not this similarity aids or hinders the potential for gender quotas to result in transformative substantive representation is a question for future research in this area, and should build on recent institutionalist considerations of how representatives from traditionally underrepresented groups adapt to the long-standing norms of the institutions they enter (Celis and Wauters, 2010). Broadly, however, advocates of gender quotas should be emboldened by our findings and oppose negative perceptions of 'quota women' where they encounter them.

\section{Bibliography}

Allen, Peter. 2013. 'Linking the pre-parliamentary political experience and political careers of the 1997 general election cohort', Parliamentary Affairs, 66:4,685-707.

Angrist, Joshua, Guido Ibens, and Donald, Rubin. 1996. 'Identification of causal effects using instrumental variables', Journal of the American Statistical Association, 91:434, 444455.

Annesley, Claire, and Francesca Gains. 2010. 'The Core Executive: Gender, Power and Change', Political Studies, 58 (5). 1-21.

Bacchi, Carol. 2006. "Arguing for and against quotas: theoretical issues. ." In Women, Quotas and Politics, ed. Drude Dahlerup. London: Routledge. 32-52.

Bauer, Gretchen. 2012. 'Let there be a Balance': Women in African Parliaments. Political Studies Review 10: pp.370-384. 
Bauer, Gretchen, and Jennie E. Burnet. 2013. Gender quotas, democracy, and women's representation in Africa: Some insights from democratic Botswana and autocratic Rwanda. Women's Studies International Forum Available online.

Borchert, Jens, and Jurgen Zeiss, eds. 2003. The Political Class in Advanced Democracies: A Comparative Handbook. Oxford: Oxford University Press.

Caul, Miki. 2001. Political Parties and the Adoption of Candidate Gender Quotas: A CrossNational Analysis. The Journal of Politics 63 (4): 1214-1229.

Celis, Karen, and Bram Wauters. 2010. Pinning the Butterfly: Women, Blue-Collar and Ethnic Minority MPs vis-à-vis Parliamentary Norms and the Parliamentary Role of the Group Representative. The Journal of Legislative Studies 16 (3): 380-393.

Childs, Sarah. 2000. The new Labour women MPs in the 1997 British Parliament: issues of recruitment and representation. Women's History Review 9 (1): 55-73

Childs, Sarah, and Mona Lena Krook. 2009. Analysing women's substantive representation: From critical mass to critical actors. Government and Opposition 44 (2): pp.125-145.

Childs, Sarah, and Mona Lena Krook. 2012. "Labels and Mandates in the United Kingdom." In The Impact of Gender Quotas, eds. Susan Franceschet, Mona Lena Krook and Jennifer M. Piscopo. New York: Oxford University Press. pp.89-102.

Childs, Sarah;, and Philip Cowley. 2011. The Politics of Local Presence: Is there a Case for Descriptive Representation? Parliamentary Affairs 59 (1): 1-20.

Cowley, Philip, and Sarah Childs. 2003. Too spineless to rebel? New Labour's women MPs. British Journal of Political Science 33 (3): 345-365.

Curtice, John, Stephen Fisher and Michael Steed. 2005. 'The results analysed', in D. Kavanagh and D. Butler (eds), The British General Election of 2005 (Basingstoke: Palgrave Macmillan), 235-259.

Cutts, David. 2006. 'Continuous activism and electoral outcomes: The Liberal Democrats in Bath', Political Geography, 25:1, 72-88.

Cutts, David, Sarah Childs, and Ed Fieldhouse. 2008. 'This is what happens when you don't listen': All-women shortlists at the 2005 General Election. Party Politics 14 (5): 575595.

Cutts, David, and Paul Widdop. 2012. Was Labour Penalised where it Stood All Women Shortlist Candidates? An Analysis of the 2010 UK General Election. British Journal of Politics \& International Relations 15 (3): pp.435-455.

Dahlerup, Drude. 2007. Electoral Gender Quotas: Between Equality of Opportunity and Equality of Result. Representation 43 (2): pp.73-92. 
Dahlerup, Drude, and Lenita Friedenvall. 2010. Judging gender quotas: predictions and results. Policy and Politics 38 (3): pp.407-425.

Devlin, Claire, and Robert Elgie. 2008. The Effect of Increased Women's Representation in Parliament: The Case of Rwanda. Parliamentary Affairs 61 (2): pp,237-254.

Fieldhouse, Edward, and David Cutts. 2009. 'The effectiveness of local party campaigns in 2005: Combining evidence from campaign spending, agent survey data and individual level data', British Journal of Political Science, 39:1, 367-388.

Franceschet, Susan, Mona Lena Krook, and Jennifer M. Piscopo, eds. 2012. The Impact of Gender Quotas. New York: Oxford University Press.

Franceschet, Susan, and Jennifer M. Piscopo. 2008. Gender Quotas and Women's Substantive Representation: Lessons from Argentina. Politics and Gender 4: pp.393-425.

Franceschet, Susan, and Jennifer M. Piscopo. 2012. "Gender and Political Backgrounds in Argentina." In The Impact of Gender Quotas, eds. Susan Franceschet, Mona Lena Krook and Jennifer M. Piscopo. New York: Oxford University Press. pp.43-56.

Jun, Uwe. 2003. "Great Britain: From the Prevalence of the Amateur to the Dominance of the Professional Politician." In The Political Class in Advanced Democracies, eds. Jens; Borchert and Jurgen Zeiss. Oxford: Oxford University Press. 164-186.

Kittlison, Miki Caul. 2006. Challenging Parties, Changing Parliaments. Columbus: Ohio State University Press.

Krook, Mona Lena. 2009. Quotas for Women in Politics. New York: Oxford University Press.

Krook, Mona Lena. 2006. Reforming Representation: The Diffusion of Candidate Gender Quotas Worldwide. Politics \& Gender 2 (03).

Krook, Mona Lena. 2013. Electoral Gender Quotas: A Conceptual Analysis. Comparative Political Studies Published online before print: pp.1-26.

Lovenduski, Joni. 2005. Feminizing Politics. London: Polity.

Murray, Rainbow. 2010a. Linear Trajectories or Vicious Circles? The Causes and Consequences of Gendered Career Paths in the National Assembly. Modern \& Contemporary France 18 (4): 445-459.

Murray, Rainbow. 2010b. Second among unequals? A study of whether France's "quota women" are up to the job. Politics and Gender 6 (1): 93-118.

Murray, Rainbow, ed. 2010c. Cracking the Highest Glass Ceiling: A Global Comparison of Women's Campaigns for Executive Office, Women and Minorities in Politics. Santa Barbara, California: Praeger. 
Murray, Rainbow. 2012. "Parity and Legislative Competence in France." In The Impact of Gender Quotas, eds. Susan Franceschet, Mona Lena Krook and Jennifer M. Piscopo. New York: Oxford University Press. pp.27-42.

Norris, Pippa;, and Joni Lovenduski. 1995. Political Recruitment: Gender, Race and Class in the British Parliament. Cambridge: Cambridge University Press.

O'Brien, Diana Z. 2012. "Quotas and Qualifications in Uganda." In The Impact of Gender Quotas, eds. Susan Franceschet, Mona Lena Krook and Jennifer M. Piscopo. New York: Oxford University Press. pp.57-71.

Oborne, Peter. 2007. The Triumph of the Political Class. London: Pocket Books.

Piscopo, Jennifer M. 2011. Rethinking Descriptive Representation: Rendering Women in Legislative Debates. Parliamentary Affairs 64 (3): pp.448-472.

Riddell, Peter. 1993. Honest Opportunism. London: Phoenix.

Ridge, Sophy. 2013. 'Does Nick Clegg really need to introduce 'sexist' all-women shortlists?', The Telegraph,[http://www.telegraph.co.uk/women/womens-politics/10411316/DoesNick-Clegg-really-need-to-introduce-sexist-all-women-shortlists.html] last accessed 10-01-2014.

Rosenbaum, Paul. and Donald Rubin. 1985. 'Constructing a control group using multivariate matched sampling methods that incorporate the propensity score', The American Statistician, 39:1, 33-38.

Russell, Meg. 2000. Women's Representation in UK Politics. London: Constitution Unit.

Sater, James N. 2012. "Reserved Seats, Patriarchy, and Patronage in Morocco." In The Impact of Gender Quotas, eds. Susan Franceschet, Mona Lena Krook and Jennifer M. Piscopo. New York: Oxford University Press. pp.72-86.

Zetterberg, Pär. 2008. The downside of gender quotas? Institutional constraints on women in Mexican state legislatures. . Parliamentary Affairs 61:3, 442-460. 


\section{Appendix}

Table A1: Socio-Economic Variables: Principal Components Analysis Varimax-Rotated Component Loadings

\begin{tabular}{|c|c|c|c|}
\hline \multirow[t]{2}{*}{1991 Census Variables } & C1 & $\mathrm{C2}$ & C3 \\
\hline & $\begin{array}{l}\text { 'Working } \\
\text { Class' }\end{array}$ & $\begin{array}{l}\text { 'Affluence } \\
\text { Suburbs' }\end{array}$ & $\begin{array}{l}\text { 'Retirement } \\
\text { \& Rurality' }\end{array}$ \\
\hline \% Agriculture & - & - & .631 \\
\hline$\% S E G 1 \& 2$ & -.725 & .605 & - \\
\hline \% Degree & -.525 & .731 & - \\
\hline$\%$ Non-White & - & - & -.681 \\
\hline$\%$ Two Cars & -.917 & - & - \\
\hline \% Manufacturing & - & -.883 & - \\
\hline \% Renting & .703 & - & - \\
\hline \% Pensioners & - & - & .840 \\
\hline \% Long Term Illness & .837 & - & - \\
\hline \% Unemployment & .899 & - & - \\
\hline Variance & $43.5 \%$ & $18.5 \%$ & $14.0 \%$ \\
\hline $\begin{array}{c}\text { Accumulated Value - \% } \\
\text { Total Variance }\end{array}$ & $43.5 \%$ & $62.0 \%$ & $76.0 \%$ \\
\hline
\end{tabular}

Notes. Components with Eigenvalues $>1$ are retained. Rotated component loadings (varimax rotation) greater than 0.4 shown.

\footnotetext{
${ }^{\mathrm{i}}$ In a single-member majoritarian system, a quota can be perceived as a zero-sum conflict between men and women candidates (Cowley and Childs, 2011), a conflict that would be less direct under a party list system. Proportional systems tend to have more women legislators regardless of quota imposition so it could be argued that the implementation of a quota will alter the political landscape less than it would for a country with a small number of women legislators.

ii Of the sixty-five newly elected women at the 1997 General Election, Sylvia Heal was first elected in 1990 and served initially until the 1992 election before losing her seat before
} 
running again in 1997. To ensure that all those women being studied are starting from the same position (i.e. new to parliament) we decided not to include her in the analysis.

iii In her study of Uganda, Diana O'Brien compares women elected to reserved seats for women to men and women elected as 'county representatives'.

iv We used a number of instruments: marginality, region, proximity to women and retired women incumbents. The instruments did not prove to be relevant in accounting for selection and further use would have led to inconsistent and misleading findings. Part of the problem is the sample size of AWS seats which was relatively small in the 1997 general election.

${ }^{\mathrm{v}}$ We calculated the conditional probability of receiving a treatment using a logistic regression of the probability of treatment as a function of the observed covariates. The small sample size of the treatment group makes it very difficult to get any meaningful findings particularly when it was necessary to distinguish between selections made in Labour incumbent and nonincumbent seats.

${ }^{v i}$ Where age is the outcome variable, the coefficient for AWS newly elected MPs was 1.10 $(\mathrm{SE}=1.39)$ when compared against those MPs elected through an open list. Where newly elected male MPs was the base category, the AWS new elected MPs coefficient remained positive but insignificant 0.68 ( $\mathrm{SE}=1.24)$ whereas the coefficient for newly elected nonquota women was negative and insignificant $-2.03(\mathrm{SE}=1.53)$.

vii Where education is treated as a continuous outcome variable, the coefficient for AWS newly elected MPs was 0.07 ( $\mathrm{SE}=0.17)$ when compared against open list MPs. Where newly elected male MPs was the base category, the AWS new elected MPs coefficient remained insignificant 0.11 ( $\mathrm{SE}=0.17$ ). The coefficient for newly elected non-quota women was also insignificant $0.21(\mathrm{SE}=0.19)$.

viii We argue that the executive presence of women can be seen as a 'hard' form of descriptive representation, and existing research suggests that it is likely to lead to the increased substantive representation of women at best, and a greater awareness of women's issues within the core executive at worst (Annesley and Gains, 2010).

ix Of the entire 1997 intake of 242 MPs elected for the first time from all parties, just over $35 \%$ remained on the backbenches for the duration of their time in the Commons, or for the entire three-term, thirteen year period of the Labour's tenure in office.

${ }^{x}$ To test the proportional odds assumption we use the Omodel command in STATA which provides us with a likelihood ratio test. The null hypothesis is that there is no difference in the coefficients between the models. We obtain a likelihood ratio chi-square value of 17.44 (prob $>\mathrm{chi}^{2}=0.49$ ) which reveals no violation of the assumption. The Brant test of parallel regression assumption provides further evidence of no violation in the assumption: Chi square value of $14.92\left(\mathrm{prob}>\mathrm{chi}^{2}=0.67\right)$. This suggests that the ordered logistic approach is an appropriate modelling procedure in this case.

xi There is no evidence of any collinearity here with the other candidate quality measures. If age and education are removed from the model, all the remaining candidate quality measures remain insignificant. 